ISSN 2414-1143

Научный альманах стран Причерноморья. 2019. Том 20. № 4

DOI 10.23947/2414-1143-2019-20-4-29-35

UDC 39:379.85

\title{
ETHNIC VILLAGES AS A FACTOR OF THE DEVELOPMENT OF ETHNIC TOURISM
}

\author{
(c) Tatiana V. Vergun \\ Autonomous Non-Profit Higher Education Organization "North Caucasus Social Institute", \\ Stavropol, Russian Federation \\ t-vergun@ya.ru
}

The article presents the role of ethnic villages in the development of ethnic tourism. It is noted that ethnic villages are a relatively new segment of the tourist market which reflects the ethnocultural mosaic of the modern world. The basis for the creation of ethnic villages is, as the title suggests, ethnos with its cultural and historical traditions, socio-economic and public-political structure. The loss of many unique and distinctive elements of ethnoculture in the condition of a globalizing world has been reflected in the search of many peoples for their identity. Tourism as a sociocultural practice of mankind has responded to these processes by establishing centers of tourist attraction such as ethnic and ethno-national settlements, villages. The concept of "ethnic village" has not been clearly recorded yet. The concept of "ethnographic", "national" and sometimes "international" village or settlement is applied to such settlements. This term can be analyzed from different positions. Ethnic villages reflect ethnocultural heritage and include natural resources management systems, ways of life, customs, a language, a cuisine, a layout, a type of settlements and buildings, forms of folk creativity, religious and other phenomena of spiritual culture. The global crises of our time, including the social and cultural crisis, the overpragmatism and commercialization of culture, and the growing threat to cultural and civilizational education have necessitated comprehensive reflection and the development of a coherent long-term strategy that would ensure the development of culture through a dialogue of civilizations.It is shown that one of the significant advantages of the development of national villages and ethnic tourist centers in the world is the support of local residents and representatives of small peoples, more precisely, cultural carriers.

Key words: ethnic tourism, ethnic village, cultural landscape, cultural property.

\section{[T.В. Вергун Этнические деревни как фактор развития этнического туризма]}

В статье рассматривается роль этнических деревень в развитии этнического туризма. Отмечается, что этнические деревни являются сравнительно новым сегментом туристского рынка, отражающим этнокультурную мозаику современного мира. Основой создания этнических деревень выступает, как и предполагает название, этнос со своими культурно-историческими традициями, социально-экономическим и государственно-политическим устройством Утрата в условиях глобализирующегося мира многих уникальных и самобытных элементов этнокультуры нашла отражение в поиске многими народами своей идентичности. Туризм как социокультурная практика человечества откликнулся на эти процессы созданием таких центров притяжения туристов, как этнические и этнонациональные поселения, деревни. Понятие «этническая деревня» четко пока что не зафиксировано. Часто в отношение таких поселений применяют понятие «этнографическая», «национальная» и иногда «интернациональная» деревня или поселение. Данный термин может анализироваться с различных позиций. Этнодеревни отражают этнокультурное наследие, включают системы природопользования, жизненные уклады, обычаи, язык, кухню, планировку, вид поселений и строений, формы народного творчества, религиозные и прочие явления духовной культуры. Глобальные кризисы современности, в том числе и кризис социокультурной сферы, чрезмерная прагматизация и коммерциализация культуры, а также растущая угроза культурному и цивилизационному образованию обусловили необходимость всестороннего осмысления и выработки согласованной долгосрочной стратегии, которая обеспечила бы развитие культуры на базе диалога цивилизаций. Показано, что одним из значительных плюсов развития национальных деревень и этнических туристских центров в мире является поддержка местных жителей и представителей малых народов, точнее, носителей культуры.

Ключевые слова: этнический туризм, этнодеревня, культурный ландшафт, культурное наследие.

Tatiana V. Vergun - Ph.D. in Philosophy, Associate Professor, Head of the Chair, department of Foreign Languages and Tourism, Autonomous Non-Profit Higher Education Organization "North Caucasus Social Institute", Stavropol, Russian Federation. 
Вергун Татьяна Викторовна - кандидат философрских наук, доцент, заведующая кафедрой иностранных языков и туризма АНО BО «Северо-Кавказский социальный институт», г. Ставрополь, Российская Федерация.

Ethnic villages are one of the relatively new segments of the tourist market which reflects the ethnocultural mosaic of the modern world. The basis for the creation of ethnic villages is, as the title suggests, ethnos with its social and historical, cultural and historical traditions [12, pp. 3-9], with socio-economic and public-political structure, historical selfconsciousness, as a part of national self-consciousness [13, pp. 41-47].

The loss of many unique and distinctive elements of ethnoculture in the condition of a globalizing world has been reflected in the search of many peoples for their identity. Tourism as a sociocultural practice of mankind has responded to these processes by establishing centers of tourist attraction such as ethnic and ethno-national settlements, villages.

The concept of "ethnic village" is quite young [5, 21 p.]. The concept of "ethnographic", "national" and sometimes "international" village or settlement is applied to such settlements. This term can be analyzed from different positions [9, 54 p.].

For example, from the point of view of ethnography, the concept of "ethnic village" is understood as a settlement that retains its ethnic type, there is a system of signs that allow to characterize the traditional culture of ethnos $[10,179 p$.$] . In the field of tourism, the concept of$ "ethnic village" is interpreted as a tourist object specially equipped for the development of ethnic, ethnographic tourism in combination with agroturism and ecotourism, as well as with other types of cultural tourism [8, 260 p.]. From the perspective of ethno-cultural landscape science, the concept of "ethnic village" is interpreted as a relatively new type of cultural landscape of the 21 st century [4, 22 p.].

The ethnic village is an imitation cultural landscape. Even in cases when the ethnic village is created on the basis of a real village, the "ethnic and village cultural landscape" acts as a model, an imitation, and sometimes a figurative stylization of the traditional village landscape with all its linking components.

The material components of the cultural landscape (natural landscape, architecture, settlement layout, elements of traditional economic activity, of agricultural and fishing) are easier to model. Considerable experience in modeling spiritual culture has been gained. As a rule, the ethnic village becomes a venue of folklore festivals, of festive rites and so on [3, 114 p.].

Ethno-national and ethnic villages contribute to the development of various types and forms of ethno-cultural tourism, including ethnographic, ethnic, nostalgic, identity, anthropological, ecological-cultural, rural, lifestyle tourism and some others [1, 27 p.]. Researchers note that tourist interest, goals and motivations in these types of tourism are determined by the following reasons and factors:

- The search for evidence of own belonging to a certain stable historical community;

- The search of own roots, knowledge of historical role, place, image of the social, ethnic, religious group;

- The search for cultural parallels between own and other national-cultural and sociocultural groups;

- The need for knowledge of public heritage;

- Historical reconstruction;

- The desire to be in virtual reality, in the idealized world [2, 175 p.].

Ethnic villages reflect ethnocultural heritage and include natural resources management systems, ways of life, customs, a language, a cuisine, a layout, a type of settlements and 
buildings, forms of folk creativity, religious and other phenomena of spiritual culture. Ethnic villages differ in purpose, functions and specificity [6, 41 p.].

The following purposes for the creation of ethnic villages are highlighted:

- Preservation of valuable, unique and typical architectural structures, traditional for the given area;

- Demonstration of planning and spatial-organizational ethnic traditions;

- Demonstration of the main household and fishing features of the ethnic group;

- Holding traditional folk holidays;

- Organization of ethnocultural tourism.

The ethnic village performs a number of quite important functions. These functions include:

- Protection of ethnographic heritage objects;

- Educational, upbringing functions;

- Recreational and tourist function.

The historical and cultural heritage of each of the peoples covers its entire sociocultural environment, including traditions and customs, peculiarities of household and economic life [11, pp. 3-10]. Ethnocultural revival is accompanied by a widespread increase in people's interest in their ethnic identity, it counteracts the phenomenon of globalization [7, $22 \mathrm{p}$.]. This revival is expressed in the maintenance or revival of ethnic traditions, folklore, life, crafts, holidays and other things.

Thanks to the ethnic revival, various ethnic parks, national villages and special programs of ethno-cultural tourism of different countries were created, where the original cultures were preserved in their original form. In addition, thanks to the desire of people to return to their roots, there is an inextricable, complex interrelation of social practices, cultural experience and cooperation between different peoples, indigenous and migrated, large and small.

At the turn of the 19th and the 20th centuries in the Nordic countries for the first time in the world there appeared the latest type of museums, the museums of folk life (architectural and ethnographic) under the open air, or ethnic villages. The first ethnic village in the world was created by Swedish enthusiast Arthur Hazelius, on the 11th of October, 1891 [5, 182 p.].

This ethnic village was named Skansen and it was opened on the island of Jurgorden on the territory of the capital of Sweden. The reason for the creation of ethnic villages was the disappearance of old buildings and household objects in Scandinavia at the turn of the 17th and the 19th centuries. The loss of cultural property led to the idea of saving them, bringing them to protected places, amassing collections of folk architecture and displaying in the parks of the cities.

Such an idea, however, was no longer new; in 1790 it was expressed by the Swiss scientist Charles de Bonstetten, who lived in Denmark. After Scansen in Sweden, the Zorgenfree Museum was built in Denmark, near Copenhagen, in 1901.

The organizers of museums were initially limited to the exposure of peasant culture, believing that the village way of life should be the most important topic of ethnographic study.

On the territory of Russia ethnic villages began to be created in the second half of the 20th century. The initial development of this phenomenon was characterized by their orientation towards the preservation of typical and unique traditional village buildings for a particular region. These are temples, residential buildings, as well as household facilities. Education and protection functions were key in the activities of the first ethnic villages [7, 24 p.].

At the initial stage of the development of ethnic villages in Russia the most typical were open-air museums, such as: "Small Corels", "Vitoslavitsy". In the organization and functioning of these museums-reserves the most important principles of their activity are the following: 
- Regionality (villages are oriented towards full territorial coverage of local cultural traditions in all their regional and ethnic appearances);

- Taking into account the cultural diversity of the region (organization of exhibitions in sectors corresponding to the local cultural traditions of the region);

- Countryside (the aspiration to present not only separate buildings, but also their "natural" environment, household grounds and natural boundaries, the correct natural landscape, landscape planning of the territory of the museum);

- Landscape (modeling of the initial landscape situation, the desire to convey harmony of traditional cultural landscape, its aesthetic perusal) [8, 260 p.].

The implementation of these principles in a situation of planned State support has borne fruit. By the end of the 1980s, full cultural and landscape complexes were built in many regions of our country, which reflected architectural, planning, decorative and other peculiarities of local cultural traditions.

However, the crisis of the 1990s in Russia has left its mark. A lot of such facilities had been suspended. Despite the crisis situation, museums-reserves have become centers for the development of regional cultural life, as well as work with external tourist flows has intensified.

In the 2000s, new directions of the development of the ethnic villages emerged. The active movement to create more new ethnic villages was linked not only to the requirements of tourism, but also to the global processes, as well as to the development of regional and local identity $[9,55$ p.].

Thus, new types of ethnic villages and new subtypes of ethnic rural cultural landscapes (national villages, regional ethnic villages of national republics, local ethnic villages, including ethnic villages of small peoples of Russia, as well as world (global) ethnic villages) appeared.

The activity based on the ethnic villages of small peoples of Russia is of a pronounced conservation and ecological-cultural nature [10, 180 p.]. The activities of the ethnic villages of small peoples are also oriented towards the popularization of spiritual culture, worldview aspects of relations with nature (complexes "Bakandyn", "Us Khatyn" and others in Yakutia; Itelmen village "Pimchi", Even Stancy "Manedek" in Kamchatka Kray; Ethnographic complex in Gornoknyazevsk village, the Yamal-Nenets Autonomous District).

World, or global, ethnic villages are of particular interest. They are an entertaining tourist product that at the same time bears an ethnic tint. A prime example of such a village is "Ethnomir", located in the vicinity of the city of Borovsk, Kaluga region. The role of national villages and ethnic tourism destinations in the world is invaluable in terms of tourism development and, as a result, in the economic and cultural development of countries.

The global crises of our time, including the social and cultural crisis, the overpragmatism and commercialization of culture, and the growing threat to cultural and civilizational education have necessitated comprehensive reflection and the development of a coherent long-term strategy that would ensure the development of culture through a dialogue of civilizations [8, 261 p.].

In the context of globalization, tourism offers new perspectives and opportunities for the protection of cultural and natural heritage, of cultural identity and intercultural exchange, which promote dialogue among different cultures. At the same time, rapprochement with foreign culture makes it possible to understand its carriers better, which, in the end, contributes to the establishment of friendly relations and peace on the planet. In particular, such issues are covered in international normative documents that regulate tourism activities. 
One of the significant advantages of the development of national villages and ethnic tourist centers in the world is the support of local residents and representatives of small peoples, more precisely, cultural carriers [6, 41 p.].

In such areas of tourism as hotel, restaurant or excursion business, it is necessary to have a certain level of education or special education, as well as to possess standard skills to meet the world requirements for the service sector. However, in ethnic tourism there is no urgent need for training of employees, as local residents are the actual carriers of information, for the sake of which tourists come [4, 22 p.]. This factor stimulates the growth of employment in small cities or underdeveloped regions of countries, as well as it increases the income of the local population.

Thanks to the creation of ethnic villages there is a revival of traditions, nations, which have long seemed lost, and preservation of their customs, rites and so on [10, 181 p.].

This is particularly relevant in today's globalized world. For example, there is a tendency for large nations to absorb smaller ones, i.e., assimilation processes. Over time, the languages of small peoples cease to be used, and as a result, ethnos ceases to exist.

As mentioned earlier, the creation of such cultural centers creates new jobs and eliminates the need for the local population to leave their home villages and towns in search of work and earnings. The difference between the major district centers and the province is offset over time with respect to the income of the population [7, 25 p.]. In addition, there is a direct benefit for the state, as revenues to the budget also increase thanks to the payment of taxes.

Thus, the principles of sustainable tourism development should be adhered to in the case of the development of such tourist destinations. It is possible to distort traditions, the way of life of local residents. The original culture can change its appearance, as a large number of tourists not only study another culture, but also leave traces of their own inadvertently. It is impossible to avoid the negative impact of the development of this type of tourism, but it is possible to mitigate its effect by careful planning and analysis of future tours, places of their passage and further control of the processes. As a major factor of globalization, tourism is experiencing its transformative influence in shaping the new context and environment of its development. Modern information and communication technologies provide an opportunity for current travellers to form individual travel programs, which allow to acquire a truly unique experience. Staying among people using a different language, preferring a different cuisine, using a different style of behaviour is a key meaning of tourism.

\section{Лumepamypa}

1. Адаева Д.О. Этнический туризм - вид или разновидность? // Научный форум. Сибирь. 2016. № 3. Т. 2. С. 26-27.

2. Бабкин А.В. Специальные виды туризма. Ростов-на-Дону: Феникс, 2008. 252 с.

3. Барлукова А.В. Классификационный статус этнического туризма // Известия ИГЭА. 2010 № 4. C. 112-119.

4. Бахтина С.М., Смирнов Д.В. Этнический туризм в России на современном этапе развития индустрии туризма / В сборнике: Управление в условиях глобальных мировых трансформаций: экономика, политика, право Сборник научных трудов Международная конференция. 2018. С. 21-23.

5. Бутузов А.Г. Этнокультурный туризм. М.: КНОРУС, 2013. 248 с.

6. Иконникова, С.Н. Культурное пространство как ценность и национальное достояние [Текст] / С.Н. Иконникова // История культурологических теорий. 2-е изд. СПб., 2005. C. $35-55$. 
7. Кржижевский М.В. Этнический туризм в Самарской области: особенности и перспективы развития // Соврем. пробл. сервиса и туризма. 2011. № 2. С. 21-27.

8. Полякова Н.В., Максимов Д.В. Этнический туризм как форма межнациональных отношений // Теоретические и прикладные аспекты современной науки. 2014. № 5-3. C. 259-261.

9. Сундуев Ч.Б., Хышиктуева Л.В. Этнотуризм как одно из направлений культурнопознавательного туризма // Вестник БГУ. 2009. № 4. С. 53-56.

10. Суртаев Б.М. Этнографический туризм как способ сохранения и возрождения этнокультурного наследия // Вестник угроведения. 2012. № 1. С. 178-182.

11. Goncharov V., Kolosova $O$. Ethnocultural aspect of the study of the social sphere as the basis of human life // Научный альманах стран Причерноморья. 2019. №3(19). С. 310.

12. Berkovskiy V., Tronina L. Social and historical aspect of interaction of ethnic culture and personality in the context of public development // Научный альманах стран Причерноморья. 2019. №1(17). С. 3-9.

13. Kuleshin M., Leonova N., Nemashkalov P. Historical consciousness as a part of national consciousness: to the problem statement of the research // Научный альманах стран Причерноморья. 2019. №1(17). С. 41-47.

\section{References}

1. Adayeva D.O. Etnicheskii turizm - vid ili raznovidnost? [Ethnic tourism - type or Variety?] Scientific Forum. Siberia. 2016. No. 3. V. 2.pp. 26-27.

2. Babkin A.V. Spetsialnye vidy turizma. [Special types of tourism]. Rostov-on-Don: Phoenix, 2008. 252 p.

3. Barlukova A.V. Klassifikatsionnyi status etnicheskogo turizma. [Classification status of ethnic tourism]. News of ISEA. 2010 No. 4. pp. 112-119.

4. Bakhtina S.M., Smirnov D.V. Etnicheskii turizm v Rossii na sovremennom etape razvitiia industrii turizma. [Ethnic tourism in Russia at the current stage of development of the tourism industry]. In the Collection: Management in the conditions of global world transformations: Economics, Politics, Law. The Collection of Scientific Works. International Conference. 2018. pp. 21-23.

5. Butuzov A.G. Etnokulturnyi turizm. [Ethnocultural tourism]. Moscow: KNORUS, 2013. $248 \mathrm{p}$.

6. Ikonnikova S.N. Kulturnoe prostranstvo kak tsennost i natsionalnoe dostoianie. [Cultural space as a value and national heritage]. S.N. Ikonnikova. History of cultural theories. The second ed. Saint Petersburg. 2005. pp. 35-55.

7. Krzyzewski M.V. Etnicheskii turizm v Samarskoi oblasti: osobennosti i perspektivy razvitiia. [Ethnic tourism in Samara Region: features and development prospects]. Modern problems of service and tourism. 2011. No. 2. pp. 21-27.

8. Polyakova N.V., Maksimov D.V. Etnicheskii turizm kak forma mezhnatsionalnykh otnoshenii. [Ethnic tourism as a form of inter-ethnic relations. Theoretical and applied aspects of modern science]. 2014. No. 5-3. pp. 259-261.

9. Sunduev Ch.B., Hishiktueva L.V. Etnoturizm kak odno iz napravlenii kul'turnopoznavatel'nogo turizma. [Ethno-tourism as one of the directions of cultural and cognitive tourism]. Journal of BSU. 2009. No. 4. pp. 53-56.

10. Surtayev B.M. Etnograficheskii turizm kak sposob sokhraneniia i vozrozhdeniia etnokul'turnogo naslediia. [Ethnographic tourism as a way of preserving and reviving 
ethnocultural heritage]. Journal of an integrated discipline, studying the languages and cultures of Finno-Ugric people. 2012. No. 1. pp. 178-182.

11. Goncharov V., Kolosova O. Ethnocultural aspect of the study of the social sphere as the basis of human life. Science almanac of Black Sea region countries. 2019. No. 3(19). pp. 3-10.

12. Berkovskiy V., Tronina $L$. Social and historical aspect of interaction of ethnic culture and personality in the context of public development. Science almanac of Black Sea region countries. 2019. No. 1(17). pp. 3-9.

13. Kuleshin M., Leonova N., Nemashkalov P. Historical consciousness as a part of national consciousness: to the problem statement of the research. Science almanac of Black Sea region countries. 2019. No. 1(17). pp. 41-47. 